\title{
Implikasi Hukum Terhadap Pembatasan Peran Serta Aparatur Sipil Negara dalam
}

\section{Proses Politik di Indonesia}

\author{
Erwin Aditya Pratama Toni Haryadi, Eddhie Praptono \\ Universitas Pancasakti Tegal \\ erwinadityapratamash@gmail.com,Toniharyadi54@gmail.com
}

praptonolaw@gmail.com

\begin{abstract}
Constitutionally, one form of political rights implementation is reflected in the right to free states, gathering and issuing minds. The right is an indicator that a country has implemented democracy. In general, the meaning of neutrality intended is the free civil apparatus of the state of the interests of certain political parties or impartially for the benefit of a particular party or not a role in the political process. This gives the meaning that the civil apparatus of the state is in no way allowed to enter the political realm. However, on the other hand, the civil apparatus of the state still has political rights to choose and be entitled to be elected in the political process, but is not allowed to actively become members and administrators of political parties. The purpose of this research is to see the extent to which the role that the civil apparatus can perform in the political process in Indonesia. This method of research uses Normati research. Data collection utilizing libraries. And the data processing is implemented qualitatively. Legal implications for the limitation of participation in civil State apparatus in the political process, in the form of first, the legal implications of the inconsistency of regulation on neutrality which includes the regulation of the rule that raises the legal gap, so it can Used by the civil State apparatus to participate actively in the political process, the blurring of the meaning of neutrality and the creation of regulatory ambiguity; Secondly, the legal implications of the breach of provisions on the limitation of participation of civil State apparatus in the political process creates administrative sanctions based on the weight of the type of violations committed by the civil apparatus Country.
\end{abstract}

Keywords: legal implications, civil state apparatus, Indonesian politics 


\begin{abstract}
Abstrak
Secara konstitusional, salah satu bentuk penerapan hak politik tercermin dalam hak untuk bebas berserikat, berkumpul dan mengeluarkan pikiran.Hak tersebut merupakan indikator bahwa suatu negara telah melaksanakan demokrasi. Secara umum, makna netralitas yang dimaksudkan adalah bebasnya Aparatur Sipil Negara dari pengaruh kepentingan partai politik tertentu atau tidak memihak untuk kepentingan partai tertentu atau tidak berperan dalam proses politik. Hal ini memberikan makna bahwa Aparatur Sipil Negara sama sekali tidak boleh masuk dalam ranah politik. Namun pada sisi lainnya, Aparatur Sipil Negara masih tetap mempunyai hak politik untuk memilih dan berhak untuk dipilih dalam proses politik, namun tidak diperkenankan aktif menjadi anggota dan pengurus partai politik. Tujuan penelitian kali ini adalah melihat sejauh mana peran yang dapat dilaksanakan aparatur sipil negara dalam proses politik di Indonesia. Metode penelitian ini menggunakan penelitian normati. Pengumpulan data memanfaatkan kepustakaan. Dan pengolahan data dilaksanakan secara kualitatif. Implikasi hukum terhadap pembatasan peran serta Aparatur Sipil Negara dalam proses politik, berupa Pertama, implikasi hukum terhadap inkonsistensi pengaturan tentang netralitas yang meliputi terdapatnya aturan yang menimbulkan celah hukum, sehingga dapat digunakan oleh Aparatur Sipil Negara untuk berperan serta aktif dalam proses politik, terjadinya pengaburan makna netralitas dan terciptanya ambiguitas regulasi; Kedua, implikasi hukum terhadap pelanggaran ketentuan tentang pembatasan peran serta Aparatur Sipil Negara dalam proses politik menciptakan sanksi administratif yang didasarkan pada berat ringannya jenis pelanggaran yang dilakukan oleh oknum Aparatur Sipil Negara.
\end{abstract}

Kata Kunci: Implikasi Hukum, Aparatur Sipil Negara, Politik Indonesia

\title{
A. Latar Belakang
}

Pada hakikatnya, demokrasi apabila dilihat dari bentuknya selalu diwarnai oleh pandangan hidup/ideologi bangsa, dimana substansinya adalah sama yaitu menunjukkan adanya peran serta aktif rakyat di dalam pemerintahan yang dilandasi persamaan dan kemerdekaan / kebebasan. ${ }^{1}$ Peran serta politik merupakan ukuran tentang betapa pentingnya kedudukan dan hubungan individu dalam negara.Hal tersebut bermakna bahwa pengakukan kebebasan dalam sistem politik merupakan konsekuensi logis atas hak-hak sipil dan politik sebagaimana termaktub dalam konsepsi hak asasi manusia melalui kehidupan kenegaraan dan kegiatan pemerintahan. ${ }^{2}$

Secara konstitusional, salah satu bentuk penerapan hak politik tercermin dalam hak untuk bebas berserikat, berkumpul dan mengeluarkan pikiran.Hak

\footnotetext{
1 Amin Rais, Demokrasi dan Proses Politik, Jakarta: LP3ES, 1986, hlm. 25.

2 Toto Pandoyo, Ulasan terhadap Beberapa Ketentuan UUD 1945 Sistem Poiltik dan Perkembangan Demokrasi, Yogyakarta: Liberty, 1981, hlm. 1.
} 
tersebut merupakan indikator bahwa suatu negara telah melaksanakan demokrasi.Setiap negara yang mengaku sebagai negara hukum yang demokratis harus memasukkan aspek peran serta aktif rakyat di dalam konstitusinya yang dilandasi persamaan dan kemerdekaan/ kebebasan. ${ }^{3}$ Di Indonesia, jaminan warga negara terhadap kebebasan berserikat, berkumpul dan mengeluarkan pikiran diatur pasal 28E UUD Negara Republik Indonesia Tahun 1945 yang menyatakan bahwa setiap orang berhak atas kebebasan berserikat, berkumpul dan mengeluarkan pikiran, sedangkan jaminan yang sifatnya diakui secara internasional diatur dalam ketentuan article 20 Declaration of Human Right. Di dalam ketentuan pasal ini dinyatakan bahwa "Everyone has the right the freedom of peaceful assembly and association and no one may be compilled to belong an association". Analog isi pasal tersebut adalah (1) setiap orang mempunyai hak atas kebebasan berkumpul dan berpendapat; (2) Tiada seorang juapun dapat dipaksa memasuki salah satu perkumpulan. ${ }^{4}$

Pada dasarnya, kebebasan sebagaimana diuraikan dalam article 20 Declaration of Human Right adalah bersifat universal, namun sebagaimana ditegaskan oleh Soewoto bahwa hak asasi ini bersifat universal, yang tidak universal adalah implementasinya dalam produk perundang-undangan. ${ }^{5}$ Hal inilah yang kemudian menimbulkan pembatasan terhadap peran serta Aparatur Sipil Negara dalam proses politik. Secara normatif, pernyataan di atas ditegaskan dalam Pasal 3 UU No. 43 Tahun 1999 yang berbunyi:

(1) Pegawai Negeri berkedudukan sebagai unsur aparatur negara yang bertugas untuk memberikan pelayanan kepada masyarakat secara

\footnotetext{
3 Sri Hartini, Hukum Kepegawaian di Indonesia, Jakarta: Sinar Grafika, 2008. hlm 61.

${ }^{4}$ Toto Pandoyo, Ulasan Terhadap Beberapa Ketentuan UUD 1945, Yogyakarta: Liberty, 1981, hlm. 95.

${ }^{5}$ Soewoto, Hak Asasi Manusia Masalah Konsep Penjabaran Pelaksanaan dan Pengawasan di Indonesia, Makalah disampaikan dalam rangka Dies Natalis Brawijaya ke 31, Universitas Brawijaya, 1 Januari 1994, Hlm. 2.
} 
profesional, jujur, adil dan merata dalam penyelenggaraan tugas negara, pemerintahan dan pembanguna

(2) Dalam kedudukan dan tugas sebagaimana dimaksud dalam ayat (1), Pegawai Negeri harus netral dari pengaruh semua golongan dan partai politik serta tidak diskriminatif dalam memberikan pelayanan kepada masyarakat.

(3) Untuk menjamin netralitas Pegawai Negeri sebagaimana dimaksud dalam ayat (2), Pegawai Negeri dilarang menjadi anggota dan/atau pengurus partai politik.

Menurut S.F Marbun, makna netralitas yang termaktub dalam Pasal 3 UU No. 43 Tahun 1999 adalah:

1. Bebasnya Aparatur Sipil Negara dari pengaruh kepentingan partai politik tertentu atau tidak memihak untuk kepentingan partai tertentu atau tidak berperan dalam proses politik. Namun Aparatur Sipil Negara masih tetap mempunyai hak politik untuk memilih, dan berhak untuk dipilih dalam pemilihan umum. Namun tidak diperkenankan aktif menjadi anggota dan pengurus partai politik;

2. Maksud netralitas yang lain adalah jika seorang Aparatur Sipil Negara aktif menjadi pengurus partai politik atau anggota legislatif, maka ia harus mengundurkan diri. Dengan demikian birokrasi pemerintahan akan stabil dan dapat berperan mendukung serta merealisasikan kebijakan atau kehendak politik manapun yang sedang berkuasa dalam pemerintahan. ${ }^{6}$

Secara umum, makna netralitas yang dimaksudkan adalah bebasnya Aparatur Sipil Negara dari pengaruh kepentingan partai politik tertentu atau tidak memihak untuk kepentingan partai tertentu atau tidak berperan dalam

\footnotetext{
${ }^{6}$ S.F Marbun, Netralitas Pegawai Negeri dalam Kehidupan Politik di Indonesia, Yogyakarta: Fakultas
} Hukum Universitas Islam Indonesia, 1998, hlm. 74. 
proses politik. Hal ini memberikan makna bahwa Aparatur Sipil Negara sama sekali tidak boleh masuk dalam ranah politik. Namun pada sisi lainnya, Aparatur Sipil Negara masih tetap mempunyai hak politik untuk memilih dan berhak untuk dipilih dalam proses politik, namun tidak diperkenankan aktif menjadi anggota dan pengurus partai politik.

Berdasarkan penjabaran di atas, maka ranah penelitian ini merupakan ranah penelitian hukum normatif dengan landasan pemikiran berupa :Pertama, kekuasaan dalam menjalankan pemerintahan dalam konteks administrasi diletakkan pada kekuasaan (eksekutif) sebagai pelaksana peran. Kedua, kekuasaan dalam penyelenggaraan pemerintahan bersumber dari wewenang formil (formil authority) yang diberikan kepada seseorang atau suatu pihak dalam bidang tertentu.Ketiga, kewenangan yagn diberikan tersebut didasarkan pada hukum yang menjadi landasan dalam melaksanakan fungsi administrasi melalui pelimpahan kekuasaan yang diberikan oleh negara. Setidak-tidaknya terdapat dua konsekuensi logis terhadap penggunaan pendekatan normatif.Pertama, pendekatan ini berkaitan dengan asas-asas dan materi muatan dalam hukum kepegawaian.Kedua, pendekatan normatif memberikan teknik tertentu pada fungsi-fungsi tertentu yang dijalani dan diaplikasikan pada suatu aktivitas tertentu, namun didalamnya terkandung akan nilai-nilai yang bersifat ideal. Keanekaragaman nilai inilah yang dipahami sebagai ilmu preskriptif yang berfungsi untuk memberikan solusi terhadap permasalahan yang terjadi.

\section{B. Rumusan Masalah}

1. Apakah yang mendasari pembatasan peran serta Aparatur Sipil Negara dalam proses politik di Indonesia?

2. Bagaimanakah implikasi hukum terhadap pembahasan peran serta Aparatur Sipil Negara dalma proses politik di Indonesia menurut perspektif Hukum Kepegawaian? 


\section{Metode Penelitian}

Penelitian ini menggunakan penelitian yuridis normatif. Penelitian yuridis normatif adalah penelitian hukum yang dilakukan dengan cara meneliti bahan pustaka yang ada. ${ }^{7}$ Penelitian ini termasuk penelitian normatif karena yang diteliti adalah peran Aparatur Sipil Negara dalam proses politik di Indonesia.

Pendekatan yang digunakan dalam penelitian ini adalah pendekatan normatif. Pendekatan normatif adalah pendekatan melalui studi kepustakaan (library research) dengan cara membaca, mengutip, dan menganalisis peraturan perundang-undangan dan teori-teori hukum yang berhubungan dengan permasalahan yang ada dalam penelitian. ${ }^{8}$ Penelitian ini menggunakan pendekatan normatif karena dilakukan dengan menelaah semua undangundang dan regulasi yang bersangkut paut dengan isu hukum yang ditangani (statute approach $)^{9}$. Penelitian ini juga dilakukan dengan menganalisa doktrin yang berkaitan dengan peran aparatur sipil negara dan proses politik berdasarkan literatur-literatur yang berkaitan dengan permasalahan yang ada dan peraturan perundang-undangan yang relevan.

Data yang digunakan adalah data sekunder, data yang diperoleh atau dikumpulkan dari berbagai bahan hukum yang berhubungan dengan penelitian $^{10}$ dengan menggunakan dokumen hukum yang terdiri dari bahan hukum primer (literatur peraturan perundang-undangan), bahan hukum sekunder (literatur hasil penelitian, jurnal yang berkaitan, dengan objek yang diteliti) serta bahan hukum tersier (berita dari internet, yang dapat menunjang data penelitian.

\footnotetext{
7 Soerjono Soekanto dan Sri Mamudji, Penelitian Hukum Normatif Suatu Tinjauan Singkat, Jakarta: PT Raja Grafindo Persada, 2009, hlm. 13-14.

${ }^{8}$ Soerjono Soekanto, Pengantar Penelitian Hukum, Jakarta: Penerbit Universitas Indonesia, 2012, hlm. 7.

${ }^{9}$ Peter Mahmud Marzuki, Penelitian Hukum Jakarta: Kencana Prenada Media Group, 2009, hlm. 93.

${ }^{10}$ Mukti Fajar dkk, Dualisme Penelitian Hukum Normatif dan Empiris, Yogyakarta: Pustaka Pelajar, 2010, hlm. 156-157.
} 
Teknik analisis data dalam penelitian ini dilakukan dengan analisis data kualitatif. Analisis data kualitatif adalah menganalisis data sesuai peruntukannya secara sistematis dan logis, sehingga memperoleh kejelasan dalam menjawab permasalahan untuk mendapatkan kesimpulan yang bersifat ilmiah. ${ }^{11}$ Penelitian ini menggunakan analisis data kualitatif karena, analisis data diperoleh setelah semua data yang dibutuhkan didapatkan.

\section{Pembahasan}

\section{Implikasi Hukum}

Implikasi berarti akibat, apabila dikaitkan dengan konteks bahasa hukum, maka implikasi hukum berarti akibat hukum yang akan terjadi berdasarkan suatu peristiwa hukum tertentu.

\section{Peran Serta}

Peran serta adalah bagaimana masyarakat dapat terlibat dalam suatu perubahan yang memungkinkan mereka mendapatkan bagian keuntungan dari kelompok yang berpengaruh. Secara sederhana, peran serta didefinisikan sebagai feedforward information (komunikasi dari pemerintah kepada masyarakat tentang suatu kebijakan) dan feedback information (komunikasi dari masyarakat ke pemerintah atas kebijakan itu).Tujuan dasar dari peran serta adalah untuk menghasilkan masukan dan aspirasi yang berguna dari warga negara dan masyarakat yang berkepentingan (public interest) dalam rangka meningkatkan kualitas pengambilan keputusan. ${ }^{12}$

\section{Aparatur Sipil Negara}

Menurut Pasal 1 angka 1 UU No. 43 Tahun 1999 tentang perubahan atas UU No. 8 Tahun 1974 tentang Pokok-pokok Kepegawaian, Aparatur Sipil

11 Anggoro Seno, Program Legislasi Daerah di Lingkungan Pemerintah Daerah sebagai Instrumen Perencanaan Pembentukkan Produk Hukum Daerah di Kota Tegal, Semarang: Tesis Magister Ilmu Hukum, Univerisitas Diponegoro, 2015, hlm. 12.

${ }^{12}$ Sherry R. Arnstein, A Leader of Citizen Participation, Journal of The American Institute of Planners dalam www.indonetasia.com, diakses tanggal 20 Oktober 2009. Pukul 19.69, hlm. 3. 
Negara adalah setiap warga negara Republik Indonesia yang telah memenuhi syarat yang ditentukan, diangkat oleh pejabata yang berwenang dan diserahi tugas dalam suatu jabatan negeri, atau diserahi tugas negara lainnya dan digaji berdasarkan peraturan perundang-undangan yang berlaku.

\section{Proses Politik}

Dalam penelitian ini, peneliti hanya membahas tentang politik yang diartikan sebagai seni dan ilmu untuk meraih kekuasaan secara konsitusional, sedangkan proses yang dimaksud adalah segala bentuk aktivitas masyarakat (individu / lembaga) untuk mengikuti/berpartisipasi aktif dalam menentukan dan mempengaruhi kepentingan partai politik tertentu guna mencapai suatu tujuan kekuasaan dalam pemerintahan.

Berdasarkan hal diatas, maka definisi dari penelitian ini adalah akibat hukum yang akan terjadi berkaitan dengan hak dan kewajiban Aparatur Sipil Negara karena terlibat dalam suatu perubahan yang memungkinkan mereka mendapatkan bagian keuntungan dari partai politik tertentu dikarenakan Aparatur Sipil Negara tersebut ikut menentukan dan menjadi bagian yang saling mempengaruhi kepentingan partai politik tertentu guna mencapai suatu tujuan kekuasaan dalam pemerintahan.

\section{Alasan yang Mendasari Pembatasan Peran Serta Aparatur Sipil Negara} dalam Proses Politik di Indonesia.

Konsep yang mendasari pembatasan peran serta politik bagi Aparatur Sipil Negara di Indonesia sangat erat kaitannya dengan hak warga negara di dalam kehidupan bernegara dan berpemerintahan. Kehidupan para penyelenggaran pemerintahan (administrator) senantiasa diarahkan dalam konteks politik kenegaraan dan kemudian berimbas pada cara berpikir, berkata dan tindakan mereka yang membentuk peta kognitif (cognitive maps) dalam pelaksanaan pekerjaannya. Peta kognitif ini merupakan suatu dasar 
dari struktur mental seseorang yang mau menerima dan mengartikulasikan tanda-tanda dari luar dirinya yang dapat membentuk kepercayaannya sehingga mampu membuat keputusan, mau melakukan atau tidak melakukan sesuatu hal. ${ }^{13}$

Berdasarkan pemikiran di atas, maka penulis memberikan analisa yang mendasari adanya pembatasan peran serta Aparatur Sipil Negara dalam proses politik melalui 3 (tiga) alasan yang melandasinya yaitu landasan filosofis, landasan historis dan landasan komparatif.

a. Landasan Filosofis

Pada tingkat filosofis, peraturan pada hakikatnya merupakan upaya untuk memperoleh kepastian, kegunaan dan keadilan hukum guna membatasi kekuasaan terhadap kemungkinan bergeraknya kekuasaan atas nalurinya sendiri, yang pada akhirnya mengarah pada penyalahgunaan kekuasaan (abuse of power). Gagasan bahwa kekuasaan harus dibatasi dikemukakan oleh Lord Acton yang mengingatkan bahwa pemerintahan selalu diselenggarakan oleh manusia dan bahwa pada manusia itu tanpa kecuali melekat banyak kelemahan. Dalilnya yang kemudian menjadi termasyur adalah "manusia yang mempunyai kekuasaan cenderung untuk menyalahgunakan kekuasaan itu, tetapi manusia yang mempunyai kekuasaan tak terbatas pasti akan menyalahgunakan secara tak terbatas pula (Power tends to corrupt, but absolute power corrupt absolutely)". ${ }^{14}$

Berdasarkan hal di atas, maka pembatasan kekuasaan memiliki korelasi yang erat dengan upaya membatasi perilaku dari penguasa, dan untuk dapat menegaskan aspek kepastian, keadilan dan kegunaan hukum, maka di dalam setiap peraturan memiliki pembatasan terhadap

\footnotetext{
${ }^{13}$ Miftah Thoha, Birokrasi dan Politik di Indonesia, Jakarta: Raja Grafindo Persada, 2007, hlm. 79.

${ }^{14}$ Mirriam Budiardjo, Dasar-dasar Ilmu Politik (Edisi Revisi), Jakarta: Gramedia Pustaka Utama, 2008, hlm. 107.
} 
keberlakuannya.Artinya tidak ada satupun peraturan yang keberlakuannya sepanjang zaman dan memenuhi kebutuhan realitas sosial yang terus berubah, sehingga setiap perubahan pada hakikatnya merupakan konsekuensi logis bagi setiap keinginan untuk memenuhi tuntutan zaman. ${ }^{15}$ Hal ini selaras dengan yang dinyatakan oleh Hart mengenai 3 (tiga) kaidah perilaku yang meliputi:

a. Kaidah pengakuan (Kaidah Rekognisi). Kaidah yang menetakan kaidah perilaku mana yang di dalam sebuah masyarakat hukum tertentu harus dipatuhi;

b. Kaidah perubahan. Kaidah yang menetapkan bagaimana suatu kaidah perilaku dapat diubah;

c. Kaidah Kewenangan. Kaidah yang menetapkan oleh siapa dan dengan melalui prosedur yang mana kaidah perilaku ditetapkan dan bagaimana suatu kaidah perilaku harus diterapkan jika dalam suatu kejadian tertentu terdapat ketidakjelasan. Kewenangan terbagi menjadi kaidah kewenangan publik dan kaidah kewenangan perdata. Kaidah kewenangan publik di bagi menjadi kewenangan pembentukan undang-undang, kewenangan kehakiman dan kewenangan pemerintahan. ${ }^{16}$

Mencermati kaidah perilaku di atas, maka di dalam hubungan hukum antar negara dengan Aparatur Sipil Negara ditegaskan tentang ketentuan pembatasan perilaku Pegawai yang bekerja dalam instansi negeri. Hubungan ini disebut dengan hubungan dinas publik yang menurut Logemann, hubungan ini terjadi bilamana seseorang mengikat dirinya

\footnotetext{
${ }^{15}$ Ellydar Chaidir, Sistem Pemerintahan Negara Republik Indonesia Pasca Perubahan Undang-Undang Dasar 1945, Yogyakarta: Total Media, 2008, hlm. 294.

${ }^{16}$ J.J.H. Bruggink, Refleksi tentang Hukum (Terjemahan Berhard Arief Sidharta), Bandung: PT. Citra Aditya Bakti, 1999, hlm. 104.
} 
untuk tunduk pada perintah dari pemerintah untuk melakukan sesuatu atau beberapa macam jabatan yang dalam melakukan sesuatu atau beberapa macam jabatan itu dihargai dengan pemberian gaji dan beberapa keuntungan lain. Hal ini berarti bahwa inti dari hubungan dinas publik adalah kewajiban bagi pegawai yang bersangkutan untuk tunduk pada pengangkatan dalam beberapa macam jabatan tertentu yang berakibat bahwa pegawai yang bersangkutan tidak menolak (menerima tanpa syarat) pengangkatannya dalam suatu jabatan yang telah ditentukan oleh pemerintah dimana sebaliknya pemerintah berhak mengangkat seseorang pegawai dalam jabatan tertentu tanpa adanya penyesuaian kehendak dari yang bersangkutan. ${ }^{17}$

Dalam penerapannya, hubungan dinas publik ini berkaitan dengan segi pengangkatan Pegawai Negeri yang dikenal dengan teori Contrac Suigeneris. Teori ini dikemukakan oleh Buys bahwa dalam Contrac Suigeneris mensyaratkan pegawai negeri harus setia dan taat selama menjadi Pegawai Negeri, meskipun dia setiap saat dapat mengundurkan diri. Dari pendapat Buys ini dapat disimpulkan bahwa selama menjadi Aparatur Sipil Negara, mereka tidak dapat melaksanakan hak-hak asasinya secara penuh. ${ }^{18}$ Karena itu, apabila Aparatur Sipil Negara akan melaksanakan hak-hak asasinya secara penuh, pemerintah dapat menyatakan yang bersangkutan bukanlah orang yang diperlukan bantuannya oleh pemerintah. Dalam kaitan ini, Philipus M. Hadjon menyatakan bahwa kajian Hukum Administrasi lebih memandang hubungan hukum kepegawaian dimaksud sebagai hubungan Openbare Dienstbetrekking (hubungan dinas publik) terhadap negara (pemerintah).

\footnotetext{
17 S.F. Marbun dan M. Mahfud MD, Pokok-pokok Hukum Administrasi Negara, Yogyakarta: Liberty, 1987, hlm. $98-99$.

${ }^{18}$ SF Marbun, Ibid. hlm 99-100.
} 
Openbare Dienstbetrekking yang melekat pada hubungan kepegawaian itul ebih merupakan hubungan sub-ordinate antara bawahan dan atasan. ${ }^{19}$

Makna pemberlakuan hubungan dinas politik adalah timbulnya pembatasan terhadap diri Aparatur Sipil Negara melalui peraturan yang dikenakan kepadanya, termasuk di dalamnya adalah hak-hak yang bersifat asasi. Dalam kaitan ini, walaupun hak asasi manusia diakui sebagai hak yang pada dasarnya tak dapat dikurangi, dirampas sedikitpun oleh siapapun, namun demikian hak asasi manusia bukanlah sesuat $\mathrm{u}$ yang bisa dinikmati tanpa batas. Terdapat adagium dalam hukum bahwa penikmatan hak seseorang dibatasi yakni oleh penikmatan hak orang lian. Hal ini memiliki makna yang sama dengan pernyataan dari John Stuart Mill bahwa suatu perbuatan (penikmatan hak) tidak menimbulkan kerugian pada orang lain, maka tidak ada legitimasi bagi negara untuk merepresi suatu penikmatan hak. ${ }^{20}$ Sebaiknya jika memang penikmatan hak akan mengganggu orang lain, maka pembatasan terhadapnya dimungkinkan terjadi. Akan tetapi, perlu ditegaskan bahwa pembatasan haruslah ditentukan dengan hukum semata-mata untuk tujuan kesejahteraan umum dalam suatu masyarakat yang demokratik.Universal Declaration of Human Rights (UDHR) menyatakan bahwa:

In the exercise of his rights and freedoms, everyone shall be subject only to such limitations as are determined by law solely for the purpose of securing due recognition and respect for the rights and freedoms of others and of meeting the just requirements of morality, public order and the general welfare in a democratic society.

Terjemahan Pasal 29 tersebut ke dalam Bahasa Indonesia adalah dalam menjalankan hak-hak dan kebebasan-kebebasannya, setiap orang

\footnotetext{
${ }^{19}$ Philipus M. Hadjon, Pengantar Hukum Administrasi Indonesia, Yogyakarta: Gadjah Mada University Press, 1994, hlm. 214.

${ }^{20}$ Satya Arinanto, Hak Asasi Manusia dalam Transisi Politik Indonesia, Jakarta: FH UI, 2003, hlm. 4.
} 
harus tunduk hanya pada pembatasan-pembatasan yang ditetapkan oleh Undang-Undang dengan maksud semata-mata untuk menjamin pengakuan serta penghormatan yang layak terhadap hak-hak kebebasankebebasan orang lain, dan untuk memenuhi syarat-syarat yang adil dalam hal kesusilaan, ketertiban dan kesejahteraan umum dalam suatu masyarakat yang demokratis.

Pada level perundangan nasional, UUD 1945 hasil amandemen memberikan pembatasan dan kewajiban hak asasi manusia dengan menyatakan setiap orang wajib menghormati hak asasi manusia orang lain dalam tertib kehidupan bermasyarakat, berbangsa dan bernegara. Lebih lanjut Pasal $28 \mathrm{~J}$ ayat (2) menyatakan :

Dalam menjalankan hak dan kebebasannya, setiap orang wajib tunduk kepada pembatasan yang ditetapkan dengan Undang-Undang dengan maksud semata-mata untuk menjamin pengakuan serta penghormatan atas hak dan kebebasan orang lain dan untuk memenuhi tuntutan yang adil sesuai dengan pertimbangan moral, nilai-nilai agama, keamanan dan ketertiban umum dalam suatu masyarakat demokratis.

Hal di atas bermakna bahwa pembatasan politik bagi Aparatur Sipil Negara dapat ditolerir sepanjang untuk menjamin pengakuan serta penghormatan atas hak dan kebebasan orang lian, dan untuk memenuhi tuntutan yang adil sesuai dengan pertimbangan moral, keamanan dan ketertiban umum dalam suatu masyarakat demokratis.

\section{b. Landasan Historis}

Berdasarkan sejarahnya, sifat dan arah hukum mengenai peran serta Aparatur Sipil Negara dalam proses politik selalu diwarnai oleh kepentingan politik penguasa. Perjalanan politik bangsa menunjukkan kecenderungan yang sangat kuat bahwa birokrasi merupakan instrumen politik yang sangat efektif yang dibangun oleh sebuah rezim guna membesarkan dan mempertahankan kekuasaan yang ada. Berkaitan 
dengan hal tersebut, untuk memperjelas perjalanan politik hukum terhadap kedudukan Aparatur Sipil Negara dapat dicermati dengan penelahaan terhadap periode kekuasaan di Indonesia yang terbagi dalam 4 (empat) masa, yaitu masa awal kemerdekaan (1945-1949), masa demokrasi liberal sampai dengan masa demorkasi terpimpin/ orde lama (19501965), masa order baru (1965-1998) dan era reformasi (1998 - sekarang).

1) Politik Hukum Pemerintah pada Masa Awal Kemerdekaan (Tahun 19451950)

Selama awal kemerdekaan, birokrasi tidak berjalan normal dan banyak dari pegawai yang terpecah belah. Selama revolusi fisik ${ }^{21}$, pemerintah mengalami kesulitan untuk menata administrasi kepegawaian dengan baik, karena lembaga yang khusus menangani administrasi kepegawaian belum terbentuk sepenuhnya. Pada awalnya, Kantor Urusan Pegawai (KUP) dibentuk berdasarkan Peraturan Pemerintah No. 11 Tahun 1948 tanggal 30 Mei 1948 dan berkedudukan di Yogyakarta. Dalam hal ini, KUP khusus diperuntukkan menanganai pegawai pemerintah RI, sedangkan pegawai yang mengabdi pada pemerintah Hindia Belanda dikelola oleh Djawatan Umum Urusan Pegawai (DUUP) yang dibentuk berdasarkan Keputusan Gubernur Jenderal Hindia Belanda No. 13 Tahun 1948, berselang beberapa hari setelah lahirnya KUP. Dikarenakan masih dalam suasana revolusi, pemerintah republik tidak sekalipun mengubah organisasi birokrasi peninggalan Belanda kecuali menambah dengan disertakan Komite Nasional dalam mekanisme pemerintahan di daerah (KND).

\footnotetext{
${ }^{21}$ Revolusi Fisik terjadi karena adanya perang dengan Tentara Sekutu pada bulan Oktober 1945, Agresi Militer Belanda I tanggal 21 Juli 1947, Pemberontakan PKI Madiun tanggal 18 September 1948, dan Agresi Militer Belanda II tanggal 19 Desember 1948.
} 
Berdasarkan penjabaran di atas, maka upaya pembatasan peran serta politik pada tahun 1945-1950 bagi Aparatur Sipil Negara belumlah ada.Hal ini terjadi karena situasi yang belum stabil dan belum adanya pengaturan tentang partai politik. Pada saat itu, aspek politik yang muncul adalah kepentingan untuk melegitimasi kekuasaan wilayah pemerintah Republik Indonesia dengan Belanda dengan cara memperatahankan dan menambah pegawai di wilayah yang dikuasai.

2) Politik Hukum Pemerintah pada Masa Demokrasi Liberal sampai dengan Demokrasi Terpimpin (Tahun 1950-1965)

Pada masa ini dikeluarkan Perpres No. 2 Tahun 1959 dan Surat Edaran (SE) Presiden Republik Indonesia No. 2 Tahun 1959 yang materinya membatasi kebebasan berpendapat sebagaimana tercantum dalam ketentuan Pasal 28 UUD 1945. Munculnya Perpres ini disebabkan oleh upaya pemerintah untuk memulihkan keadaan PNS yang pada saat itu berlarut-larut dalam permainan politik. Namun secara umum, perubahan politik ke era Demokrasi Terpimpin (1959-1966) tidak menghasilkan perubahan mendasar dalam proses birokratisasi kecuali perubahan peta kekuatan politik yang ditandai melalui tiga konteks : Pertama, peranan partai politik mulai termarjinalisasikan sebagai aktor utama dalam sistem politik; Kedua, menonjolkan figur Presiden Soekarno sebagai patron kekuasaan; dan Ketiga, masuknya kekuatan militer secara resmi ke pentas politik, menempati banyak jabatan strategis pemerintahan dari pusat hingga daerah. Menurut Moh. Mahfud, keadaan pada masa demokrasi terpimpin juga dipengaruhi oleh produk hukum saat ini.Presiden menghendaki adanya Demokrasi Terpimpin, produk hukum yang dikeluarkan saat itu juga memiliki karakteristik yang dapat mendukung kebijakan Presiden.Demokrasi 
Terpimpin merupakan perwujudan kehendak Presiden dalam rangka menempatkan dirinya yang paling berkuasa di Indonesia. ${ }^{22}$

3) Politik Hukum Pemerintah pada Masa Orde Baru (1965-1998)

Pada era Orde Baru terdapat ciri-ciri dari model birokrasi yang berpolitik yaitu terbentuknya wadah tunggal organisasi yaitu KORPRI, Bureaucratic Polity/ Korporatisme Negara, Monoloyalitas Birokrasi/PNS saat Pemilu terhadap Partai Politik Pemerintah.Masyarakat Orde Baru dapat ditandai melalui dua hal.Pertama, pola kontestasi kekuatan politik berubah dari polarisasi dan pertarungan antar-parpol dan politisi sipil ke pola dominasi militer dan Golongan Karya (Golkar). Kedua, proses marjinalisasi parpol secara umum terus berjalan seiring dengan tampilnya unsur birokrasi dan kekuatan militer yang kian memantapkan posisi sebagai aktor sentral.

4) Politik Hukum Pemerintah pada Era Reformasi (Tahun 1998-saat ini)

Pada Era Reformasi, dikeluarkannya beberapa peraturan yang membatasi peran serta Aparatur Sipil Negara dalam proses politik. Adapun ciri-ciri dari model netralitas politik birokrasi pada era Reformasi yaitu KORPRI dinyatakan independen dari Partai Politik, birokrasi tidak berafiliasi politik, birokrasi berjarak dengan Partai Politik, peran LSM dan kelompok kepentingan lebih leluasa dan masyarakat berpartisipasi secara otonom untuk membangun civil society.

\section{c. Landasan Komparatif}

Penulis memperbandingkan aturan yang berkaitan dengan hak politik bagi Aparatur Sipil Negara di Amerika dan Inggris.Landasan pemilihan 2 (dua) negara terebut dikarenakan Amerika Serikat merupakan negara

${ }^{22}$ Afan Gafar, Politik Indonesia Transisi Menuju Demokrasi, Yogyakarta: Pustaka Pelajar, 2000, hlm. 29. 
dengan sistem pemerintahan demokratis yang menghormati hak-hak individual, memelihara keseimbangan antara kebebasan dan ketertiban, uniformitas dengan diversitas dan hak-hak individu dengan kebutuhan kolektif.Dalam hal ini, Amerika Serikat menerapkan sistem hukum kepegawaian yang memiliki sifat yang liberal.Kerajaan Inggris dipilih karena memiliki bentuk pemerintahan monarki dengan sistem pemerintahan parlementer yang menganut paham demokrasi liberal. Menurut C.F Strong, Kerajaan Inggris akan memberikan suatu ilustrasi sempurna tentang negara kesatuan yang proses pengintegrasiannya melalui penggabungan (kesatuan). ${ }^{23} \mathrm{Hal}$ ini bermakna bahwa Inggris merupakan negara yang secara historis memiliki sistem hukum yang berkembang secara evolutif (termasuk dalam hukum kepegawaiannya).

Berdasarkan analisis terhadap pengaturan hak politik di Amerika Serikat dan di Inggris diketahui bahwa penggunaan sistem patronage ternyata menimbulkan permasalahan secara administratif, oleh karena itu partai-partai yang bersaing sepakat untuk memperbaiki manajemen kepegawaian dengan menjadikannya sebagai pegawai-pegawai negeri milik negara yang selalu siap digunakan oleh setiap partai pemenang di parlemen. Sejak itu, dibinalah Aparatur Sipil Negara dengan disiplin tersendiri ke arah profesional. Dengan perkembangan pembinaan Aparatur Sipil Negara ke arah merit system, maka diatur jarak atau keikutsertaan Aparatur Sipil Negara dalam kegiatan politik praktis melalui konsep netralitas, yang antara lain dengan cara penghapusan spoil system menciptakan Aparatur Sipil Negara di Inggris memiliki sifat yang

${ }^{23}$ C.F. Strong, Konstitusi-konstitusi Politik Moderen Studi Perbandingan tentang Sejarah dan Bentuk-bentuk Konstitusi Dunia (Terjemahan SPA Teamwork), Bandung: Nuansa dan Nusamedia, 2004, hlm. 118. 
permanen, Anonimitas dan Netral sedangkan pembatasan hak politik bagi Aparatur Sipil Negara di Amerika Serikat berupa:

1) Yang diterima menjadi pegawai federal harus mempunyai kesetiaan kepada negara bukan kepada partai;

2) Untuk jabatan-jabatan tertentu diberlakukan ketentuan melarang menjadi simpatisan partai politik.

3) Kebijakan di atas kelihatannya mengurangi hak politik pegawai negeri, namun ternyata tidak dianggap merugikan diri pegawai yang bersangkutan, bahkan dalam beberapa hal dianggap sebagai kebanggan. ${ }^{24}$

\section{Implikasi Hukum Terhadap Pembatasan Peran Serta Aparatur Sipil Negara}

\section{dalam Proses Politik menurut Perspektif Hukum Kepegawaian.}

Implikasi hukum adalah akibat hukum yang akan terjadi berdasarkan suatu peristiwa hukum tertentu. Hal ini memberikan makna bahwa dalam implikasi hukum terkandung unsur hubungan hukum antarperson, peristiwa hukum dan akibat hukum. Makna implikasi hukum apabila dikorelasikan dengan pembatasan peran serta Aparatur Sipil Negara, maka ini memiliki makna berupa:

1. Adanya suatu penghormatan terhadap sebagian peranan yang diberikan oleh pemerintah pada Aparatur Sipil Negara;

2. Adanya suatu aturan untuk melarang penggunaan sebagian peranan lainnya yang diberikan pada Aparatur Sipil Negara;

3. Timbulnya suatu akibat hukum berupa sanksi administratif tatkala terdapatnya pelanggaran atas sebagian peranan yang telah dilarang.

${ }^{24}$ Dharma Setiawan Salam, Manajemen Pemerintahan Indonesia, Jakarta: Djambatan, 2007, hlm. 194. 
Mencermati ketiga unsur di atas, maka secara keseluruhan dapat ditarik implikasi hukum terhadap pembatasan peran serta Aparatur Sipil Negara dalam proses politik yang meliputi:

a. Terhadap inkonsistensi pengaturan tentang netralitas

1) Terdapatkan aturan yang menimbulkan celah hukum sehingga dapat digunakan oleh Aparatur Sipil Negara untuk berperan aktif dalam proses politik. Hal ini disebabkan oleh aturan yang berlaku kurang tegas (limitative), namun lebih bersifat enumeratif sehingga menimbulkan kerancuan atau pertentangan interpretasi. Sebagai contoh adalah substansi Pasal 11 ayat (2) UU No. 43 Tahun 1999 yang memberikan gambaran bahwa Aparatur Sipil Negara pada saat menjabat sebagai pejabat negara diberhentikan dari jabatan organiknya tanpa kehilangan statusnya sebagai Pegawai Negeri. Hal ini bermakna bahwa dimungkinkan seorang Aparatur Sipil Negara ikut serta ikut serta dalam proses pemilihan umum kemudian mengundurkan diri (sementara dari jabatan organiknya) dan setelah tidak terpilih atau terpilih menjadi pejabat negara, kembali menjadi Pegawai Negeri Sipil.

2) Terjadinya pengaburan makna netralitas Aparatur Sipil Negara sebagaimana tercantum dalam Pasal 3 UU No. 43 Tahun 1999 tentang Dibolehkannya Aparatur Sipil Negara menjadi pejabat negara melalui proses pemilihannya yang bersifat politis. Pengaturan tentang mekanisme pemilihan tersebut kemudian mengiliangkan makna netral karena dalam praktiknya akan terjadi tarik ulur kepentingan di antara kepentingan politik dan kekuasaan;

3) Dibolehkannya Aparatur Sipil Negara menjadi peserta kampanye dan memiliki hak pilih. Dua hal yang bertentangan tersebut mengindikasikan bahwa pemerintah masih kesulitan dalam 
menempatkan makna netral dari pengaruh politik dan golongan tertentu. Apabila Aparatur Sipil Negara ikut menjadi peserta kampanye, maka jelas dia memposisikan diri menjadi tidak netral, apalagi ketika dia memberikan hak pilihnya. Hal ini menimbulkan implikasi bahwa makna netralitas tidaklah relevan untuk dicantumkan dalam Pasal 3 UU No. 43 Tahun 1999.

4) Terciptanya ambiguitas regulasi, karena pembatasan hak politik Aparatur Sipil Negara yang dimaksudkan untuk menciptakan profesionalitas dalam diri Aparatur Sipil Negara menjadi kabur karena pengaturan tentang kedudukan pejabat pembina Aparatur Sipil Negara Daerah diserahkan kepada Kepala Daerah yang notabene merupakan pejabat politik yang dipilih melalui mekanisme politik.

b. Implikasi hukum terhadap pelanggaran ketentuan tentang pembatasan peran serta Aparatur Sipil Negara dalam proses politik meliputi:

1) Hukum tingkat berat berupa penurunan pangkat setingkat lebih rendah untuk paling lama 1 (satu) tahun diberikan bagi:

a) PNS yang melibatkan PNS lainnya untuk memberikan dukungan dalam kampanye

b) PNS yang duduk sebagai Panitia Pengawas Pemilihan tanpa seijin dari Pejabat Pembina Kepegawaian atau Atasan Langsung.

2) Hukuman Disiplin tingkat berat berupa pemberhentian dengan hormat tidak atas permintaan sendiri sebagai PNS dengan hak-hak kepegawaian sesuai peraturan perundang-undangan yang berlaku:

a) Bagi PNS yang terlibat dalam kegiatan kampanye untuk mendukung Presiden dan Wakil Presiden, anggota DPR, DPRD Provinsi/Kabupaten/Kota, DPD, Kepala Daerah dan Wakil Kepala Daerah. 
b) Bagi PNS yang menggunakan fasilitas yang terkait dengan jabatannya dalam kegiatan kampanye.

c) Bagi PNS yang menjadi anggota Panitia Pemilihan Kecamatan (PPK), Panitia Pemungutan Suara (PPS) dan Kelompok Penyelenggara Pemungutan Suara (KPPS), tanpa ijin dari Pejabat Pembina Kepegawaian atau Atasan Langsung.

3) Hukuman Disiplin tingkat berat berupa pemberhentikan tidak dengan hormat sebagai Aparatur Sipil Negara:

a) Bagi PNS yang menggunakan anggaran Pemerintah dan Pemerintah Daerah dalam proses pemilihan Presiden dan Wakil Presiden, anggota DPR, DPRD Provinsi/Kabupaten/Kota, DPD, Kepala Daerah dan Wakil Kepala Daerah.

b) Bagi PNS yang menggunakan fasilitas yang terkait dengan jabatannya dalam proses pemilihan Presiden dan Wakil Presiden, anggota DPR, DPRD Provinsi/ Kabupaten/Kota, DPRD, Kepala Daerah dan Wakil Kepala Daerah.

c) Bagi PNS yang membuat keputusan dan atau tindakan yang menguntungkan atau merugikan salah satu pasangan calon selama masa kampanye.

\section{Simpulan}

1. Landasan filosofis menggambarkan pembatasan hak politik Aparatur Sipil Negara menurut konsepsi negara hukum demokratis yang berorientasi pada penerapan good governance guna menciptakan perubahan kaidah perilaku yang menempatkan hubungan dinas publik dalam hukum kepegawaian. Adapun pembatasan politik bagi Aparatur Sipil Negara dapat ditolerir sepanjang menjamin pengakuan serta penghormatan hak dan kebebasan orang lain, dan memenuhi tuntutan adil sesuai dengan pertimbangan moral, 
keamanan dan ketertiban umum dalam suatu masyarakat demokratis. Landasan historis menunjukkan bahwa perjalanan politik bangsa memiliki kecenderungan menempatkan birokrasi sebagai instrumen politik yang dibangun oleh sebuah rezim guna membesarkan dan mempertahankan kekuasaan. Landasan komparatif menggambarkan bahwa di Amerika Serikat dan Inggris terdapat pembatasan hak politik bagi Aparatur Sipil Negara. Hal ini dikarenakan adanya pembaharuan sistem patronage ke arah merit system. Melalui merit system, diatur jarak atau keikutsertaan pegawai negeri dalam kegiatan politik praktis melalui konsep netralitas di Inggris, hak politik Aparatur Sipil Negara dibatasi dengan menggunakan sifat yang permanen, anonimitas dan netral, sedangkan di Amerika terdapat pembatasan dalam The Hatch Act bahwa warga negara yang diterima menjadi pegawai federal harus mempunyai kesetiaan kepada negara dan jabatan tertentu diberlakukan ketentuan melarang menjadi simpatisan partai politik.

2. Implikasi hukum terhadap pembatasan peran serta Aparatur Sipil Negara dalam proses politik, berupa Pertama, implikasi hukum terhadap inkonsistensi pengaturan tentang netralitas yang meliputi terdapatnya aturan yang menimbulkan celah hukum, sehingga dapat digunakan oleh Aparatur Sipil Negara untuk berperan serta aktif dalam proses politik, terjadinya pengaburan makna netralitas dan terciptanya ambiguitas regulasi; Kedua, implikasi hukum terhadap pelanggaran ketentuan tentang pembatasan peran serta Aparatur Sipil Negara dalam proses politik menciptakan sanksi administratif yang didasarkan pada berat ringannya jenis pelanggaran yang dilakukan oleh oknum Aparatur Sipil Negara.

3. Substansi Pasal 11 Undang-Undang No. 43 Tahun 1999 tentang Pokok-pokok Kepegawaian perlu diuji materiil karena menimbulkan penafsiran ganda dalam pelaksanaannya; 
a. Penggunaan definisi netralitas Aparatur Sipil Negara kurang relevan sebaiknya kata netralitas Aparatur Sipil Negara diganti dengan pembatasan hak politik Aparatur Sipil Negara;

b. Perlu adanya perubahan pengaturan terhadap pejabat pembina kepegawaian daerah yang memiliki kewenangan pengangkatan, pemindahan dan pemberhentian Aparatur Sipil Negara;

c. Pada satu sisi, pembatasan memiliki tujuan yang baik, namun disisi lain, pembatasan tersebut terindikasi merugikan dan menghilangkan hak politik Aparatur Sipil Negara. Seharusnya, kekhawatiran akan Aparatur Sipil Negara dalam melaksanakan tugas dan kewajibannya dinilai berlebihan, sebab dengan situasi dan kondisi masyarakat yang sudah demikian terbuka, tidak cukup menjadi alasan pembenar untuk membatasi hak-hak politik bagi Aparatur Sipil Negara.

\section{Daftar Pustaka}

Arinanto Satya, Hak Asasi Manusia dalam Transisi Politik Indonesia, Jakarta: FH-UI, 2003.

Bruggink J.J.H, Refleksi tentang Hukum (Terjemahan Berhard Arief Sidharta), Bandung: PT. Citra Aditya Bakti, 1999.

Budiardjo Mirriam, Dasar-dasar Ilmu Politik (Edisi Revisi), Jakarta: Gramedia Pustaka Utama, 2008.

Chaidir Ellydar, Sistem Pemerintahan Negara Republik Indonesia Pasca Perubahan Undang-Undang Dasar 1945, Yogyakarta: Total Media, 2008.

Gaffer Afan, Politik Indonesia : Transisi Menuju Demokrasi, Yogyakarta: Pustaka Pelajar, 2000.

Hartini Sri dkk, Hukum Kepegawaian di Indonesia, Jakarta: Sinar Grafika, 2008. 
M. Hadjon Philipus dkk, Pengantar Hukum Administrasi Indonesia, Yogyakarta: Gadjah Mada University Press, 1994.

Marbun S.F. dan M. Mahfud MD, Pokok-pokok Hukum Administrasi Negara, Yogyakarta: Liberty, 1987.

Marbun S.F, Netralitas Pegawai Negeri dalam Kehidupan Politik di Indonesia, Yogyakarta: Fakultas Hukum Universitas Islam Indonesia, 1998.

Pandoyo Toto, Ulasan terhadap Beberapa Ketentuan UUD 1945 Sistem Poiltik dan Perkembangan Demokrasi, Yogyakarta: Liberty, 1981.

Purbacaraka Purnadi dan Soerjono Soekanto, Perundangundangan dan Yurisprudensi, Bandung: PT Citra Aditya Bakti, 1993.

Rais Amin, Demokrasi dan Proses Politik, Jakarta: LP3ES, 1986.

Setyawan Dharma Salam, Manajemen Pemerintahan Indonesia, Jakarta: Djambatan, 2007.

Sherry R. Arnstein, A Leader of Citizen Participation, Journal of The American Institute of Planners dalam www. indonetasia.com, diakses tanggal 20 Oktober 2009, 1969.

Soekanto Soerjono dan Sri Mamudji, Penelitian Hukum Normatif Suatu Tinjauan Singkat, Jakarta: Raja Grafindo Persada. 1983.

Soemitro Rony Hanitijo, Metode Penelitian Hukum dan Jurimetri, Jakarta: Ghalia Indonesia, 1986.

Soewoto, Hak Asasi Manusia Masalah Konsep Penjabaran Pelaksanaan dan Pengawasan di Indonesia, Makalah disampaikan dalam rangka Dies Natalis Brawijaya ke-31 Universitas Brawijaya 1 Januari 1994, 1994.

Strong C.F, Konstitusi-konstitusi Politik Modern : Studi Perbandingan tentang Sejarah dan Bentuk-bentuk Konstitusi Dunia (Terjemahan SPA Teamwork), Bandung: Nuansa dan Nusamedia, 2004.

Thoha Miftah, Manajemen Kepegawaian Sipil di Indonesia, Jakarta: Kencana, 2005. 

GEDUNG Q FAKULTAS HUKUM UNIVERSITAS PANCASAKTI TEGAL

Jl. Halmahera Km. 01, Kota Tegal | Telepon: (0283) 358745

Website: www.diktum.upstegal.ac.id | email: diktum@upstegal.ac.id

Birokrasi dan Politik di Indonesia, Jakarta: Raja Grafindo Persada, 2007. 